Bangladesh J. Plant Taxon. 20(2): 135-144, 2013 (December)

(C) 2013 Bangladesh Association of Plant Taxonomists

\title{
MICROMORPHOLOGICAL AND ANATOMICAL FEATURES OF FOUR SPECIES OF ELYTRIGIA DESV. (POACEAE)
}

\author{
Lin Meng ${ }^{1}$ and Peichun Mao \\ Beijing Research and Development Center for Grass and Environment, Beijing Academy of \\ Agriculture and Forestry Sciences, Beijing 100097, China
}

Keywords: Elytrigia Desv.; Micromorphology; Anatomy; SEM.

\begin{abstract}
The micromorphological and anatomical characters of Elytrigia caespitosa (K. Koch) Nevski, E. intermedia (Host) Nevski $\times$ E. elongata (Host) Nevski, E. intermedia (Host) Nevski and E. repens (L.) Desv. ex Nevski have been studied using Scanning Electron Microscope (SEM) to determine interspecific variation. The results show that the root transverse section consists of epidermis, cortex and stele. Two rings of vascular bundles and a central pith cavity appear in stem morphology. The leaves of E. caespitosa have either single or twin, horseshoe-shaped short cells born along the costal zone of the upper epidermis, which lack prickle hairs and contain spherical or oblique-shaped papillae. In E. intermedia, the parallel subsidiary cells are distributed on the upper epidermis, and there are no short cells in the leaves. Dome-shaped subsidiary cells appear on the upper epidermis of E. intermedia $\times E$. elongata and E. repens, but E. intermedia $\times$ E. elongata showes spot-shaped papillae, and its bulliform cells sank into the "hinge cells". E. repens has no papillae, and its bulliform cells are not sunken into the mesophyll. Therefore, the differences in micromorphological characters on the upper epidermis of the leaf could be useful in classifying and determining phylogenetic relationships among the species.
\end{abstract}

\section{Introduction}

Plant morphological feature is largely controlled by the genes of a species, but it can also be influenced by the environment (Sattler and Rutishauser, 1997; Liu, 2006). Therefore, the micromorphological and anatomical characters of root, stem and leaf can reflect the relationship between habitat and phylogenetics of plants (Liu, 2006). Elytrigia Desv. is a perennial rhizomatous grass of the family Poaceae. There are about 50 species of Elytrigia throughout the world (Chen and Jia, 2000; Lv et al., 2007), and many of them are ecologically and economically important. Elytrigia intermedia is valued for its high quality forage, E. repens for stabilizing slopes and sandy soil (Chen and Jia, 2000), and E. intermedia and E. elongata for breeding distant hybrids of wheat (Lv et al., 2007; Webb and Alrneida, 1990). Several authors have shown that the leaf epidermal morphology of the grass family has taxonomic significance because of the fine morphological structure (Chen et al., 1993; Cai and Guo, 1995). The anatomy of roots, stems and leaves of E. elongata and E. intermedia were examined and analyzed using Scanning Electron Microscope (SEM) showing that the two species have significant differences in leaf epidermal micromorphology (Shi et al., 2009), e.g. three to four rows of papillae are distributed along the costal zone of E. elongata leaves, but three to four rows of prickle hairs are distributed along the costal zone of $E$. intermedia. Therefore, the present study aims to contribute to the micromorphological and anatomical features of the roots, stems and leaves of the four species, E. caespitosa,

${ }^{1}$ Corresponding author: E-mail: menglin9599@sina.com 
E. intermedia $\times$ E. elongata, E. intermedia and E. repens, using Scanning Electron Microscopy (SEM), and to evaluate the differences of the micromorphological characters for systematic purposes.

\section{Materials and Methods}

Seeds of Elytrigia caespitosa $(\mathrm{K}$. Koch) Nevski, E. intermedia (Host) Nevski $\times$ E. elongata (Host) Nevski, E. intermedia (Host) Nevski and E. repens (L.) Desv. ex Nevski were collected from the National Plant Germplasm System (NGPS) of USA in 2007; and planted at the experimental sites of the National Experiment Station of Precision Agriculture (NESPA), Xiao Tangshan, about $55 \mathrm{~km}$ far from Beijing (Lat. 39 $34^{\prime} \mathrm{N}$, Long. 116 $28^{\prime} \mathrm{E}$ ) in 2008. Twenty seedlings of each species were planted in $80 \mathrm{~cm} \times 80 \mathrm{~cm}$ rows. Five healthy individuals for each of the four species were selected at the heading stage in May, 2009. Samples were collected by cutting $5 \mathrm{~mm}$ segments from the middle sections of the second functional leaves, mature roots, and between the stem stipe of each plant. There were two repetitions totaling 40 specimens. All specimens were pre-fixed for about 3-4 h in 3\% glutaraldehyde, and then fixed for more than $12 \mathrm{~h}$ in $1 \%$ osmic acid $\left(\mathrm{H}_{2} \mathrm{OSO}_{4}\right)$. The stationary liquid was formulated using a $\mathrm{pH} 7.2$ phosphate buffer solution (PBS). All specimens were cleaned ultrasonically 3-5 times using PBS, then dehydrated in a $30 \%, 50 \%, 70 \%, 85 \%, 95 \%$ and $100 \%$ alcohol solution for 15 min each step by step, and laid in isoamyl acetate. The $\mathrm{CO}_{2}$ critical point was obtained using a HCP-2 Critical Point Dryer (Hitachi Co. Ltd., Japan), and coated with gold by IB-5 Vacuum Ion Sputter (Eiko Engineering Co. Ltd., Japan).

Mature leaves, roots and stems are examined with S-570 Scanning Electron Microscope (Hitachi Co. Ltd., Japan), and are analyzed with WD-5 Online Photo Management System for SEM (Analysis and Examination Center, Wuhan University of China). The characteristics of the epidermal micromorphology of the upper leaves, including the length of long cells, the shape, density and distribution of short cells and papillae, the density and distribution of prickle hairs and the stomata cell parameters, and the leaf transverse section parameters, such as leaf thickness and characteristics of bulliform cells are thoroughly examined and analyzed. Root anatomical features, including the number of vascular bundles, diameter of stele, thickness of cortex and diameter of metaxylem, and the stem anatomical features including the density of vascular bundles, thickness of cuticle and diameter of inner cycle vessel, are also examined and analyzed. Each index has 10 data points, measured using Photoshop, and means are calculated. Statistical analyses are conducted using SPSS, 13.0 version. The standard leaf micro-morphological terminology is mainly adopted from Chen et al. (1993), Cai and Guo (1995), Cai (2000), Kocsis et al. (2004) and Torre (2004), whereas terminology for the morphology of roots, stems and leaf transverse sections are adopted from Liu (2006).

\section{Results and Discussion}

Root micromorphological characters:

Generally, three parts including the epidermis, cortex and stele are found in the root transverse section of four Elytrigia species. The epidermis is made up of a layer of tightly packed cells with many epidermal hairs (root hairs). Under the epidermis is exodermis with larger 2-3 layered cortex cells, which has thicker cell walls and no intercellular spaces. The endodermis is a single layer of small, tightly packed cells, each of which has five thick sides and are the horseshoe type with the passage cell. There are 2-3 layers of cells adjoining the endodermis to the thick cell wall and the radialized sequence, and the cell volume becomes larger from inner to outer layers. The stele includes the pericycle, vascular bundles and marrow. The pericycle is a layer of 
parenchymatous cells adjoining the endodermis. The exarch vascular bundle is polyarch xylem, and the centre of the stele contains the marrow filled with parenchyma (Fig.1). The comparative result of root anatomical features of the four Elytrigia species is presented in Table 1.

Table 1. Comparison of root anatomical features of four Elytrigia species.

\begin{tabular}{lcccc}
\hline Species & $\begin{array}{c}\text { No. of vascular } \\
\text { bundles }\end{array}$ & $\begin{array}{c}\text { Diameter of stele } \\
(\mu \mathrm{m})\end{array}$ & $\begin{array}{c}\text { Thickness of } \\
\text { cortex }(\mu \mathrm{m})\end{array}$ & $\begin{array}{c}\text { Diameter of } \\
\text { metaxylem }(\mu \mathrm{m})\end{array}$ \\
\hline E. caespitosa & 13 & $466.57 \pm 5.36 \mathrm{a}$ & $102.25 \pm 2.56 \mathrm{a}$ & $36.13 \pm 4.41 \mathrm{a}$ \\
E. intermedia $\times$ E. elongata & 10 & $442.43 \pm 15.81 \mathrm{a}$ & $59.52 \pm 7.17 \mathrm{c}$ & $31.03 \pm 6.38 \mathrm{~b}$ \\
E. intermedia & 9 & $456.97 \pm 14.09 \mathrm{a}$ & $73.76 \pm 11.53 \mathrm{~b}$ & $35.83 \pm 2.48 \mathrm{a}$ \\
E. repens & 5 & $323.69 \pm 17.77 \mathrm{~b}$ & $91.90 \pm 3.92 \mathrm{ab}$ & $29.54 \pm 3.61 \mathrm{~b}$ \\
\hline
\end{tabular}

Different small letters in the same column indicate significant differences at $P<0.05$.

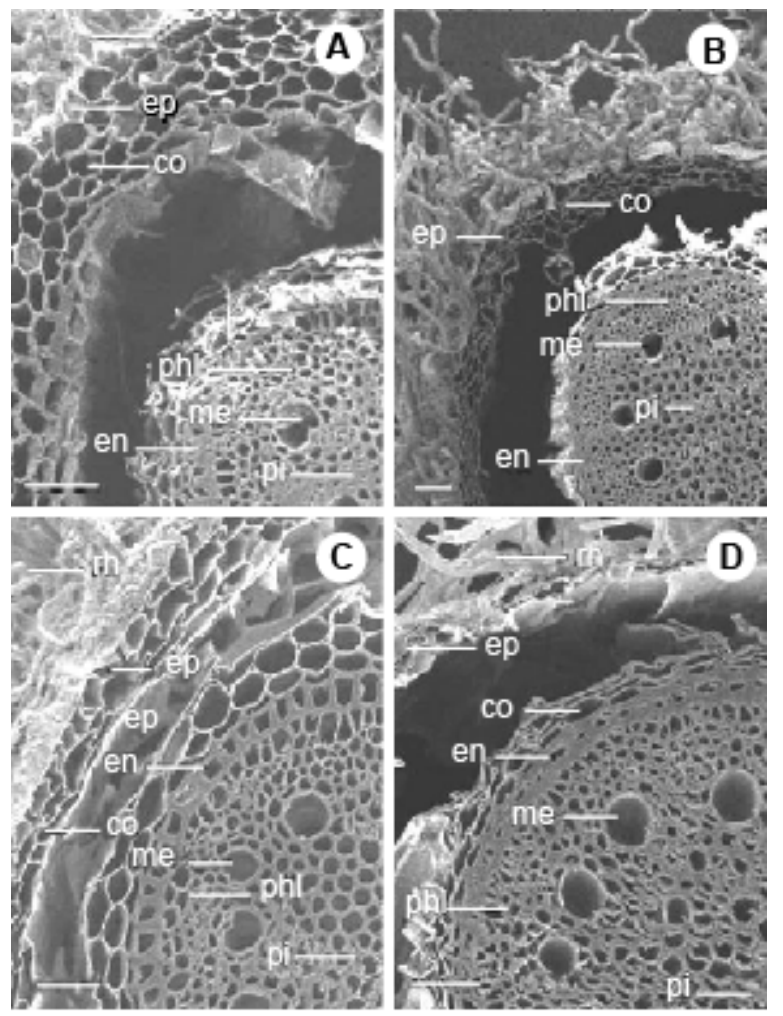

Fig. 1. Root transverse sections of four Elytrigia species. A) E. repens, B) E. intermedia, C) E. intermedia $\times$ E. elongata and D) E. caespitosa. rh: root hair; ep: epidenmis; co: cortex; phl: phloem; en: endodermis; me: metaxylem; pi: pith (A, B and $\mathrm{D} \times 200, \mathrm{C} \times 150$, scale bars $=50 \mu \mathrm{m})$.

There are approximately 13 vascular bundles in E. caespitosa, which is significantly different than $E$. repens $(P<0.05)$, that has only 5 vascular bundles. E. intermedia $\times E$. elongata, and $E$. intermedia have 10 and 9 vascular bundles, respectively, and do not differ significantly $(P>0.05)$. However, the thickness of the cortex of E. caespitosa (about $102.25 \mu \mathrm{m}$ ) is 1.72 times than that of 
$E$. intermedia $\times E$. elongata. There are no significant differences among stele diameters of $E$. caespitosa, E. intermedia $\times E$. elongata and E. intermedia $(P>0.05)$, but diameters are significantly larger than those of E. repens $(P<0.05)$, which is only $323.69 \mu \mathrm{m}$.

Table 2. Comparison of stem anatomical features of four Elytrigia species.

\begin{tabular}{lccc}
\hline Species & $\begin{array}{c}\text { Density of vascular } \\
\text { bundles } \\
\left(\text { number } \mathrm{mm}^{-2}\right)\end{array}$ & $\begin{array}{c}\text { Thickness of cuticle } \\
(\mu \mathrm{m})\end{array}$ & $\begin{array}{c}\text { Diameter of inner cycle } \\
\text { vessel }(\mu \mathrm{m})\end{array}$ \\
\hline E. caespitosa & $9 \pm 0.21 \mathrm{ab}$ & $4.01 \pm 0.09 \mathrm{a}$ & $34.47 \pm 0.80 \mathrm{~b}$ \\
E. intermedia $\times$ E. elongata & $8 \pm 0.23 \mathrm{~b}$ & $4.89 \pm 0.14 \mathrm{a}$ & $35.08 \pm 1.01 \mathrm{~b}$ \\
E. intermedia & $8 \pm 0.14 \mathrm{~b}$ & $5.22 \pm 0.09 \mathrm{a}$ & $51.67 \pm 0.89 \mathrm{a}$ \\
E. repens & $10 \pm 0.35 \mathrm{a}$ & $4.26 \pm 0.15 \mathrm{a}$ & $31.15 \pm 1.08 \mathrm{~b}$ \\
\hline
\end{tabular}

Different small letters in the same column indicate significant differences at $P<0.05$.

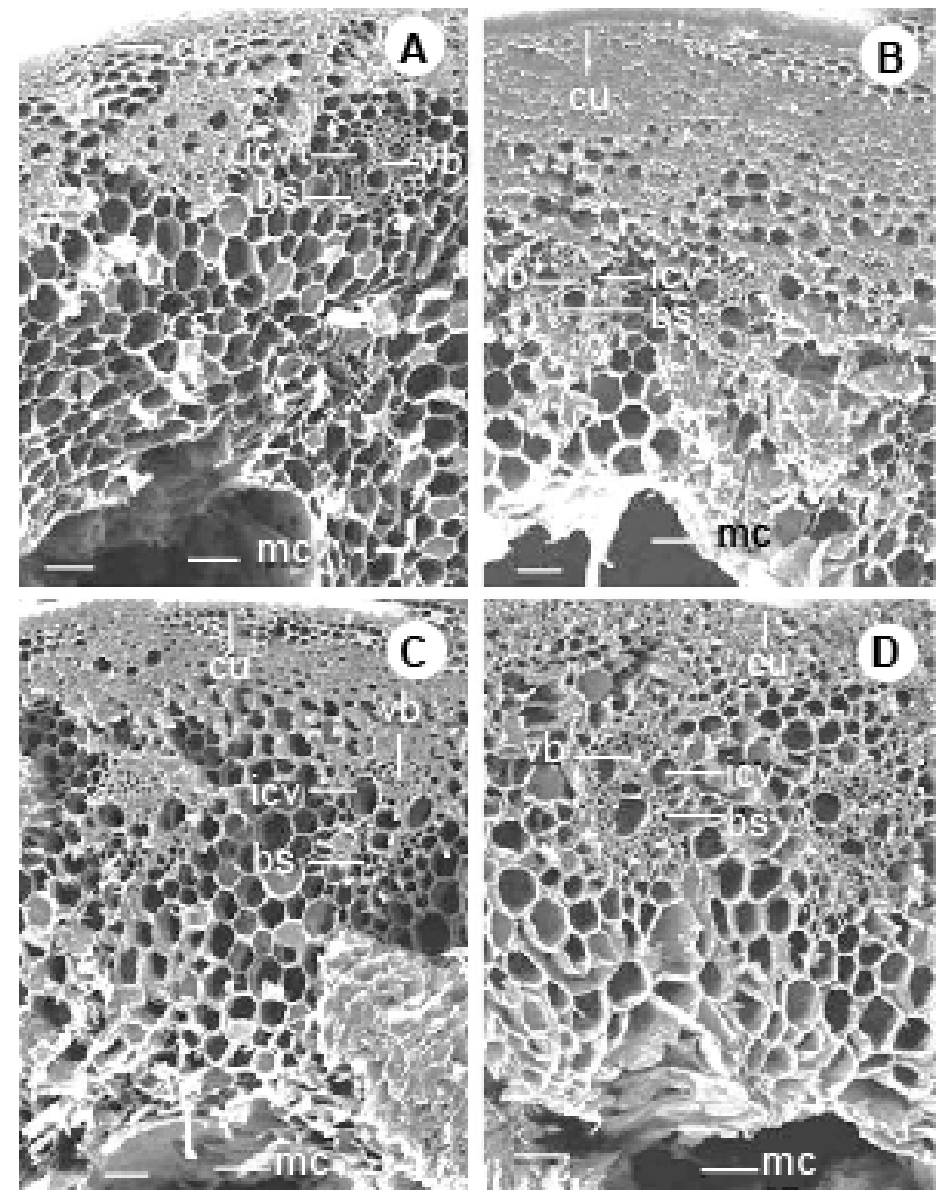

Fig. 2. Stem transverse sections of four Elytrigia species. A) E. repens, B) E. intermedia, C) E. intermedia $\times$ E. elongata and D) E. caespitosa. vb: vascular bundle; bs: bundle sheath; icv: inner cycle vessel; cu: cuticle; mc: medullary cavity $(\times 100$, scale bars $=50 \mu \mathrm{m})$. 


\section{Stem micromorphological characters:}

Stem transverse sections of the four Elytrigia species consist of four parts: the epidermis, ground tissue, vascular bundles and the medullary cavity (Fig. 2). Cuticle thickness in the epidermis is only about 4.01-5.22 $\mu \mathrm{m}$. Under the epidermis are two to three layers of sclerenchyma tissue (fiber) with thick cell walls, which are composed of parenchymatous cells. The collateral vascular bundle with sheath and no cambium are arranged in two rings. The outer ring contains small vascular bundles, which are embedded under the fiber and form the mechanical tissue, and parenchymatous cells are presented among the vascular bundles. The inner ring is composed of larger vascular bundles, and these are distributed among the parenchyma between the medullary cavity and the outer mechanical tissue (Fig. 2).

The cuticle thickness of four species do not differ significantly $(P>0.05)$, but the density of the vascular bundles in $E$. repens differs from $E$. intermedia $\times E$. elongata and $E$. intermedia $(P<0.05)$. The diameter of the inner cycle vessel in $E$. intermedia is wider than that of $E$. caespitosa, E. intermedia $\times E$. elongata and E. repens, but there are no significant differences in the inner cycle vessel diameters among the latter three species (Table 2).
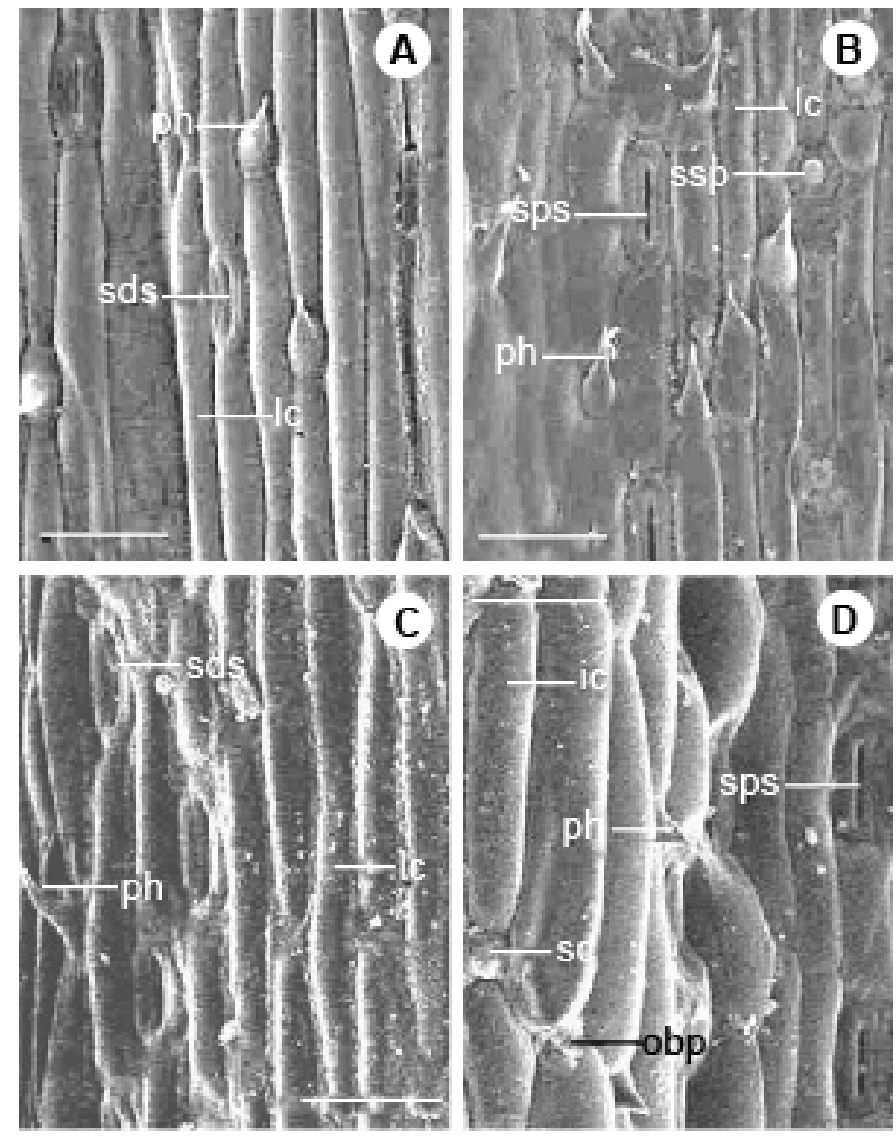

Fig. 3. Upper leaf epidermis of four Elytrigia species. A) E. repens, B) E. intermedia, C) E. intermedia $\times$ E. elongata and D) E. caespitosa. lc: long cell; sc: short cell; ph: prickle hair; obp: oblique papillae; ssp: spot-shaped papillae; sds: stomata with dome-shaped subsidiary cell; sps: stomata with parallel subsidiary cell $(\times 200$, scale bars $=50 \mu \mathrm{m})$. 


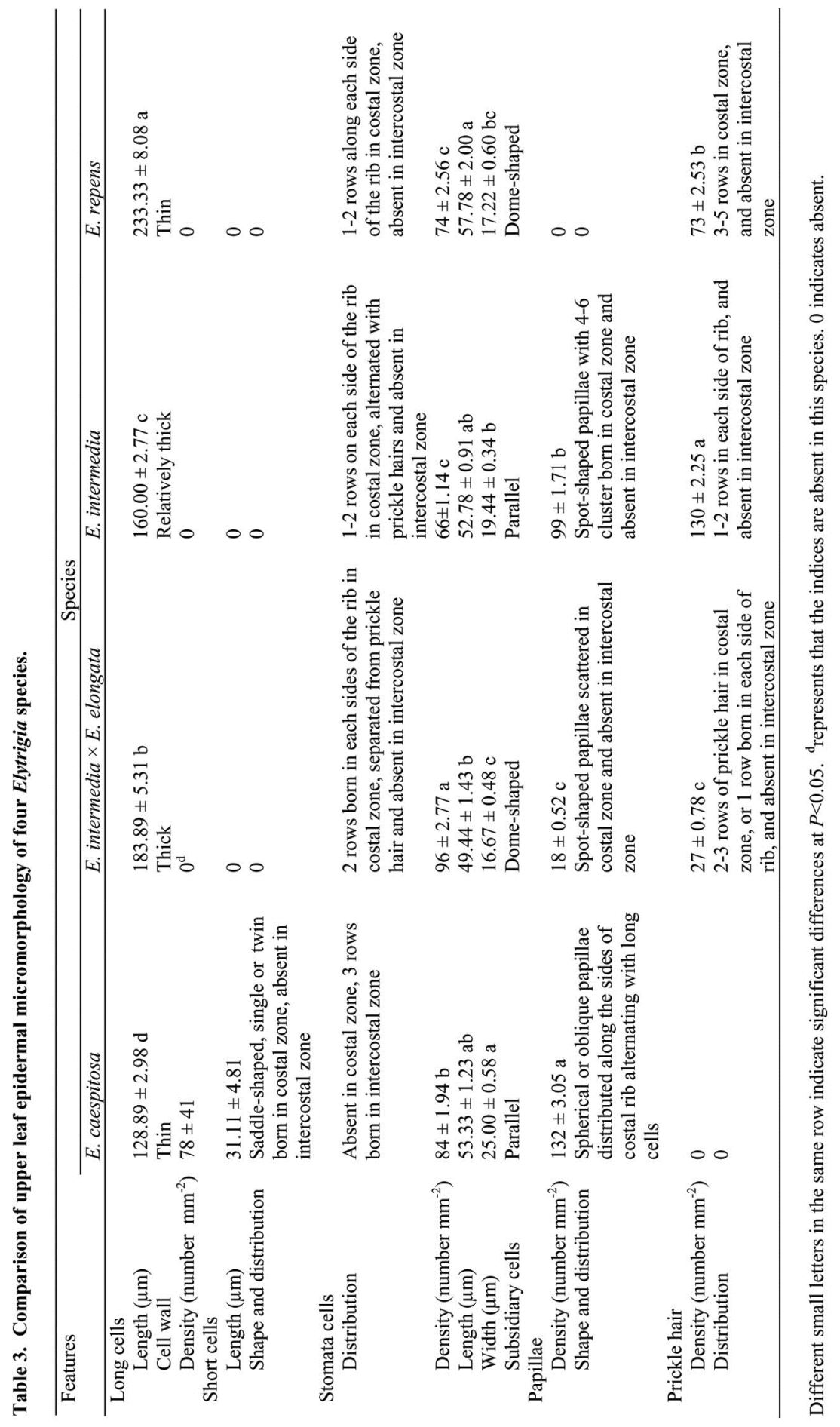




\section{Leaf micromorphological characters:}

The micromorphology and anatomy of the leaves in the four Elytrigia species comprise three layers: epidermis, mesophyll and leaf veins. The epidermis is composed of long cells, subsidiary cells and stomatal and bulliform cells. Quadrate long cells with thin or thick cell walls are arranged in parallel along the length of the costal and intercostal zones, and many of them show slight wave bending pattern (Fig. 3). The cells of E. repens are the longest $(233.33 \mu \mathrm{m})$, whereas those of $E$. caespitosa are the shortest $(128.89 \mu \mathrm{m})$. The short cells only appear in the epidermis of E. caespitosa at a density of about $78 \mathrm{~mm}^{-2}$. They are saddle shaped, single or twin, and born along the costal zone, but absent in the intercostal zone. Three rows of stomatal cells are present in the intercostal zone of the upper epidermis of E. caespitosa, and 1-2 rows appear along each side of the ribs in the costal zone for E. intermedia $\times E$. elongata, E. intermedia and E. repens. The density, length and width of the stomatal cells of the four species are expressed differently, and the subsidiary cells of $E$. caespitosa and $E$. intermedia are in parallel, but $E$. intermedia $\times$ E. elongata and $E$. repens are dome-shaped. The papillae of $E$. caespitosa are spherical or oblique in shape and are distributed along the sides of the costal rib alternating with the long cells, at a density of about $132 \mathrm{~mm}^{-2}$. E. intermedia $\times$ E. elongata and E. intermedia show spot-shaped papillae scattered throughout the costal zone. The density of papillae in E. intermedia $\times$ E. elongata is $18 \mathrm{~mm}^{-2}$ but papillae are absent in E. repens. The density of prickle hairs in E. intermedia is $130 \mathrm{~mm}^{-2}$, which is significantly different than that of E. repens $\left(73 \mathrm{~mm}^{-2}\right)$ and E. intermedia $\times$ E. elongata $\left(27 \mathrm{~mm}^{-2}\right)$ $(P<0.05)$ (Table 3).

The transverse section of leaves consists of epidermis, vascular bundles, mesophyll cells and fiber, i.e., sclerenchyma tissue (Fig. 4). Bulliform cells are present in the intercostal zones of all four species. However, those of E. intermedia $\times$ E. elongata are sunken into the mesophyll and form "hinge cells", whereas those of the other species do not show this pattern. The ratio of leaf thickness of intercostal zones to thickness of bulliform cells of the four species is approximately 17.8-28.8\%, and that of E. intermedia $\times$ E. elongata and E. repens are significantly different $(P<0.05)$ compared with $E$. caespitosa and $E$. intermedia. The average costal and intercostal thicknesses of E. caespitosa and E. intermedia $\times E$. elongata are greater than those of $E$. intermedia and E. repens (Table 4) and the veins are hump shaped. There are two layers of vascular bundles in the veins: smaller, thick cell walls in the inner layer, and larger, thin cell walls in the outer layer. Fiber is distributed along each side of the vascular bundles. The mesophyll tissue is made up of parenchymatous cells with large intercellular spaces, and there is no cellular differentiation between the palisade and spongy tissues (Fig. 4).

Table 4. Comparison of leaf transverse section of four Elytrigia species.

\begin{tabular}{|c|c|c|c|c|c|c|}
\hline \multirow[t]{2}{*}{ Species } & \multicolumn{3}{|c|}{ Leaf thickness } & \multicolumn{3}{|c|}{ Bulliform cell } \\
\hline & $\begin{array}{l}\text { Costal zones } \\
(\mu \mathrm{m})\end{array}$ & $\begin{array}{l}\text { Intercostal zones } \\
(\mu \mathrm{m})\end{array}$ & $\begin{array}{l}\text { Average } \\
(\mu \mathrm{m})\end{array}$ & Characters & $\begin{array}{l}\text { Thickness } \\
\qquad(\mu \mathrm{m})\end{array}$ & $\begin{array}{l}\text { Ratio of bulli- } \\
\text { form cell }(\%)^{\mathrm{d}}\end{array}$ \\
\hline E. caespitosa & $250.33 \pm 5.78 b$ & $166.48 \pm 3.84 \mathrm{a}$ & $208.41 \pm 4.81 \mathrm{a}$ & Not sunken & $29.67 \pm 0.69 b$ & $17.8 \pm 0.41 \mathrm{~b}$ \\
\hline $\begin{array}{l}\text { E. intermedia } \\
\times \text { E. elongata }\end{array}$ & $280.04 \pm 8.08 \mathrm{a}$ & $154.63 \pm 4.46 \mathrm{a}$ & $217.33 \pm 6.27 \mathrm{a}$ & $\begin{array}{l}\text { Sunken into } \\
\text { mesophyll and } \\
\text { form 'hinge cell' }\end{array}$ & $41.04 \pm 1.18 \mathrm{a}$ & $26.5 \pm 0.76 \mathrm{a}$ \\
\hline E. intermedia & $186.74 \pm 3.23 \mathrm{c}$ & $122.67 \pm 2.12 b$ & $154.70 \pm 2.68 b$ & Not sunken & $23.63 \pm 0.41 \mathrm{c}$ & $19.3 \pm 0.33 b$ \\
\hline E. repens & $197.37 \pm 6.84 \mathrm{c}$ & $100.41 \pm 3.48 c$ & $126.89 \pm 4.40 \mathrm{c}$ & Not sunken & $28.93 \pm 1.00 \mathrm{~b}$ & $28.8 \pm 1.00 \mathrm{a}$ \\
\hline
\end{tabular}

Different small letters in the same column indicate significant differences at $P<0.05$.

${ }^{d}$ means that the ratio of bulliform cell thickness to leaf thickness. 

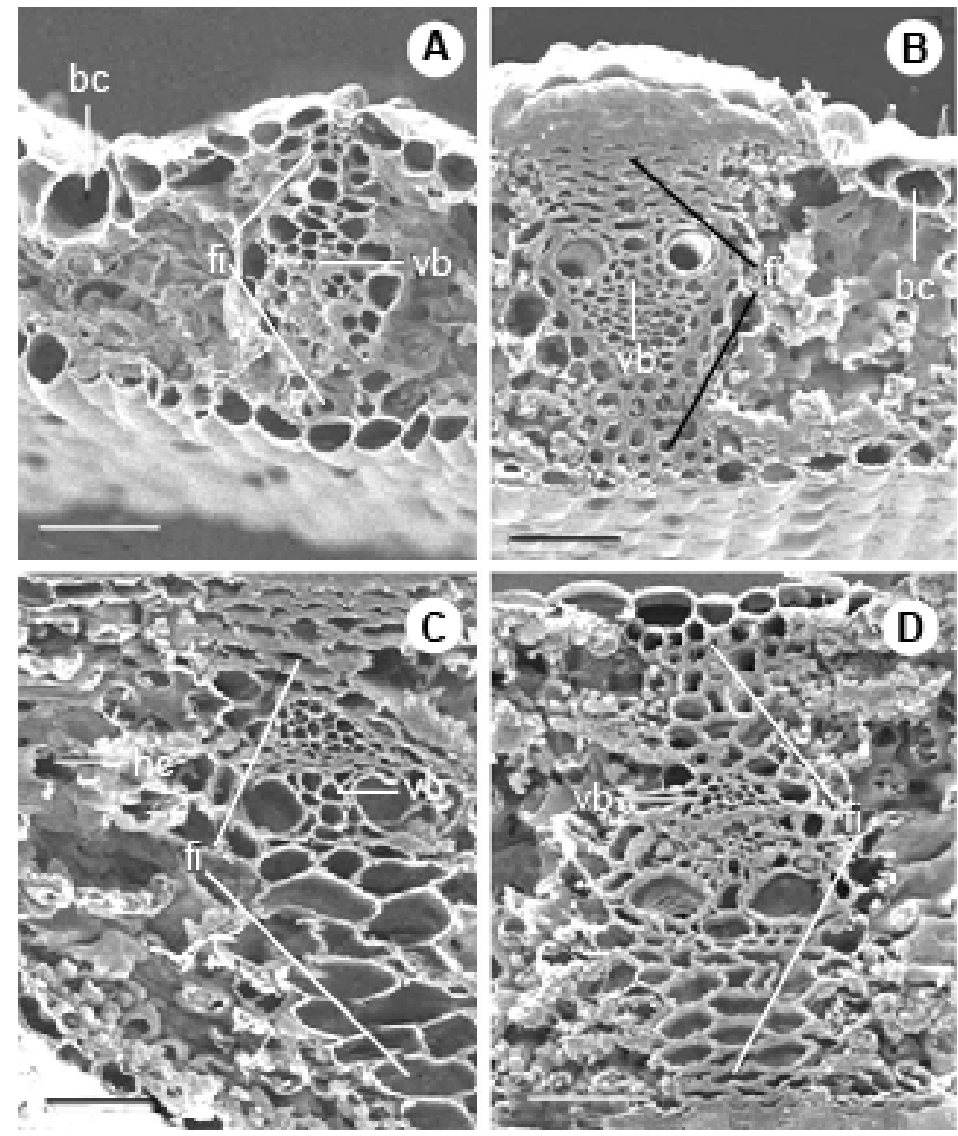

Fig. 4. Leaf transverse sections of four Elytrigia species. A) E. repens, B) E. intermedia, C) E. intermedia $\times$ E. elongata and D) E. caespitosa. bc: bulliform cell; hc: hinge cell; fi: fibre; vb: vascular bundle ( $\times 300$, scale bars $=50 \mu \mathrm{m})$.

Leaf micromorphological and anatomical characters are useful tool for plant identification and bears taxonomic significance (Cai and Guo, 1995; Shi et al., 2009; Cai and Zhang, 2006; Kahraman et al., 2010). The present investigation of the leaf anatomy of four Elytrigia species agree with those in previous studies of E. intermedia and E. elongata (Shi et al., 2009).

Based on leaf micromorphological and anatomical characters of four Elytrigia species a dichotomous key is presented below:

1. Single or twin short cells born along the costal zone, no prickle hairs on the upper epidermis.

E. caespitosa

- No short cells, but prickle hairs on the upper epidermis.

2. Subsidiary cells on the upper epidermis are parallel. 2

- Subsidiary cells on the upper epidermis are dome-shaped.

E. intermedia

3. Long cells thick-walled; papillae spot-shaped; bulliform cells sunken into mesophyll forming "hinge cell".

- $\quad$ Long cells thin-walled; papillae absent; bulliform cells not sunken into mesophyll.

E. intermedia $\times$ E. elongata

E. repens 
Bulliform cells are unique characteristics of the leaves of endemic xerophytic graminaceous plants (Cai, 2000). These cells are also known as motor cells, which can cause the leaf blades to curve or spread through the leaf during periods of water loss and absorption. Usually, the bulliform cells appear in groups along the interveins in the upper epidermis of grasses. Wang and Wang (1989) found that the bulliform cells sunk into the mesophyll and formed "hinge cells" on the upper epidermis of Bouteloua breviseta, increasing leaf curvature. However, Qiang et al. (2007) in Carex orbicularis and Guo et al. (2007) in Blysmus sinocompressus showed that bulliform cells with a little and smaller morphology appeared above the main vein of the leaves. In our study bulliform cells appear in all four Elytrigia species, but they are only embedded in the mesophyll into the "hinge cell" in E. intermedia $\times$ E. elongata. The parallel or dome-shaped subsidiary cells in the leaves of grasses exhibit plant adaptation to drought and cold (Cai and Guo, 1995). Therefore, having parallel subsidiary cells in E. caespitosa and E. intermedia and domeshaped subsidiary cells in E. intermedia $\times E$. elongata, and $E$. repens confirm that these species are capable to resist heavy drought and cold.

\section{Acknowledgements}

This work was supported by the Natural Science Foundation of China (No. 30571321; No. 31272489), Key Projects in the National Science \& Technology Pillar Program in the Eleventh Five-year Plan Period (No. 2008BADB3B05) and the Natural Science Foundation of Beijing (No. 6082009). We are grateful to Mr G. D. Shi for helping in examining the specimens.

\section{References}

Cai, L.B. 2000. Leaf epidermical characters of some species of Roegneria and their taxonomic significance. Bull. Bot. Res. 20(4): 372-378.

Cai, L.B. and Guo, Y.K. 1995. Studies on constituent cells of leaf epidermis, systematics and phylogenetic path of the family Poaceae. Acta Botanica Boreali-Occidentalia Sinica 15(4): 323-335.

Cai, L.B. and Zhang, T.L. 2006. Genetic relationship between Leymus and its related taxa in terms of the anatomical characteristics of their leaves. Acta Botanica Boreali-Occidentalia Sinica 26(3): 537-543.

Chen, M.J. and Jia, S.X. 2000. Forage Plants in China. China Agriculture Press, Beijing, China, pp. 125-128.

Chen, S.L., Jin, Y.X. and Wu, Z.J. 1993. Leaf epidermal characteristic atlas of the family Poaceae. Jiangsu Science and Technology Press, Nanjing, China, pp. 59-63.

Guo, M., Qiang, K.B. and Zhang, X.Q. 2007. Study on morphological anatomy of leaf in Blysmus sinocompressus. J. Gansu Agri. Univ. 42(1): 82-87.

Kahraman, A., Celep, F. and Dogen, M. 2010. Anatomy, trichome morphology and palynology of Salvia chrysophylla Stapf (Lamiaceae). S. Afri. J. Bot. 76(2): 187-195.

Kocsis, M., Darok, J. and Borhid, A. 2004. Comparative leaf anatomy and morphology of some neotropical Rondeletia (Rubiaceae) species. Plant Syst. Evol. 248: 205-218.

Liu, M. 2006. Morphology and Anatomy of Seed Plant (3rd edition). Science Press, Beijing, China, pp.121268.

Lv, W.D., Xu, P.B. and Pu, X. 2007. Summary of the situation for applying genetic resources from Elytrigia in Triticum aestivum breeding. Acta Prataculturae Sinica 16(6): 36-140.

Qiang, K.B., Guo, M. and Zhang, X.Q. 2007. Studies on the morphology and anatomy of leaves of Carex orbicularis. Acta Prataculturae Sinica 16(2): 76-83.

Sattler, R. and Rutishauser, R. 1997. The fundamental relevance of morphology and morphogenesis to plant research. Annals Bot. 80(5): 571-582.

Shi, G.D., Mao, P.C., Zhang, G.F., Meng, L. and Zhang, D.G. 2009. SEM observation on anatomical structure of Elytrigia elongata (Host) Nevski and E. intermedia (Host) Nevski. Prataculturae Science 26(8): 52-56. 
Torre, S. 2004. Morphology and Anatomy: Leaves. In: Roberts, A.V. (Ed.), Encyclopedia of Rose Science. Academic Press, London. Pp. 497-504.

Wang, X.L. and Wang, J. 1989. Plant Morphological Structure and Environment. Lanzhou University Press, Lanzhou, China, pp. 65-148.

Wang, Y.J. 2005. Bulliform cell of grass family. Biology Education 30(11): 7-9.

Webb, M.E. and Alrneida, M.T. 1990. Micromorphology of the leaf epidermis in the taxa of the AgropyronElymus complex (Poaceae). Bot. J. Linn. Soc. 103: 153-158.

(Manuscript received on 17 October, 2012; revised on 29 October, 2013) 